\title{
Husband-Wife Agreement, Power Relations And Contraceptive Use in Turkey
}

\begin{abstract}
CONTEXT: In Turkey, contraceptive use has become more widespread, but little is known about the concurrence of spousal reports or the relative influence of communication, decision making and power differentials on method use.

METHODS: Data from the 1998 Turkish Demographic and Health Survey (DHS) for 1,546 married couples were tested for concurrence between spousal reports on fertility and family planning variables. Multivariate regression analyses based on wives', husbands' and joint reports of current contraceptive use were used to assess the association between such use and various background, communication and interspousal variables.
\end{abstract}

RESULTS: Spousal reports on most fertility and contraceptive use measures demonstrated moderate to high concordance, whereas reports of approval of family planning showed only fair concordance. After adjusting for background factors, models based on wives' and husbands'reports showed that current contraceptive use was positively associated with the number of methods known (odds ratios, 1.2 and 1.1, respectively) and perception of spousal approval (3.3 and 2.0, respectively), and in the husbands' model, with approval of either spouse or both (3.8-5.8). In the combined model, contraceptive use was positively associated with both partners approving of family planning (2.4), and negatively associated with both partners wanting more than three children and with only wives wanting three or fewer ( 0.4 and 0.6, respectively).

CONCLUSIONS: Discrepancies between spousal reports were less significant in Turkey than in most developing countries with DHS data, but the differences were not inconsequential to explaining how spousal attitudes and preferences influence contraceptive use. No evidence was found associating interspousal power differentials with method use. Further research is needed to improve the testing and modeling of such dyadic processes.

International Family Planning Perspectives, 2008, 34(3):127-137

\section{By Andrzej \\ Kulczycki}

Andrzej Kulczycki is associate professor, Department of Maternal and Child

Health, University of

Alabama at

Birmingham, Birmingham, AL, USA.
There are very few couple-level studies of communication and decision making regarding contraceptive use in the Middle East. In Turkey-a predominantly Muslim nation that has a secular democracy and is undergoing considerable social change-fertility has declined significantly, men play a major role in contraceptive practice and women's position in society is increasingly contested. These factors make Turkey a particularly interesting country for couplelevel studies.

Traditionally, the measurement of contraceptive use has been based solely on women's self-reports of current use. Although this is methodologically convenient, the individual and subjective experiences of partners may differ. A more comprehensive measure of a couple's contraceptive use requires information from each partner. Moreover, because contraceptive practice and fertility are interrelated, the married couple is the appropriate unit of analysis, especially in societies such as those in the Middle East, where the vast majority of contraceptive use and almost all births occur within marriage.

For this region, only a few fertility and family planning surveys have collected data from men or couples. The 1992 Egyptian Demographic and Health Survey (DHS) included a subsample of husbands, and the 1992 Moroccan
DHS interviewed married and unmarried men aged 20-70, but we could not identify any couple-level studies using these data. The 1985 Jordan Husbands' Fertility Survey interviewed the husbands of women who were currently married when interviewed in the 1983 Jordan Fertility and Family Health Survey. Although one study presented some comparisons of spousal reports about contraceptive knowledge and family planning attitudes from these two Jordanian surveys, ${ }^{1}$ the comparisons were purely descriptive and limited in scope, and responses for husbands and wives were from different survey years. The 1988 Turkish Population and Health Survey collected limited data from men. A comparison of spousal reports revealed a high percentage of agreement about fertility measures, but only about three-quarters of the women knew their husbands' age and level of education (72\% and 78\% agreement, respectively, between spouses). ${ }^{2}$ A decade later, the 1998 Turkish DHS collected detailed couple-level data, including data on gender expectations and attitudes from each partner, which are analyzed in the current study.

This study has three objectives. First, it assesses the extent of interpartner concordance on self-reported aspects of reproductive decision making and behavior. Such an assessment may permit verification of the accuracy of either 
FIGURE 1. Trends in contraceptive prevalence rate and total fertility rate among currently married women aged 15-49, by survey year, Turkey, 1978-2003

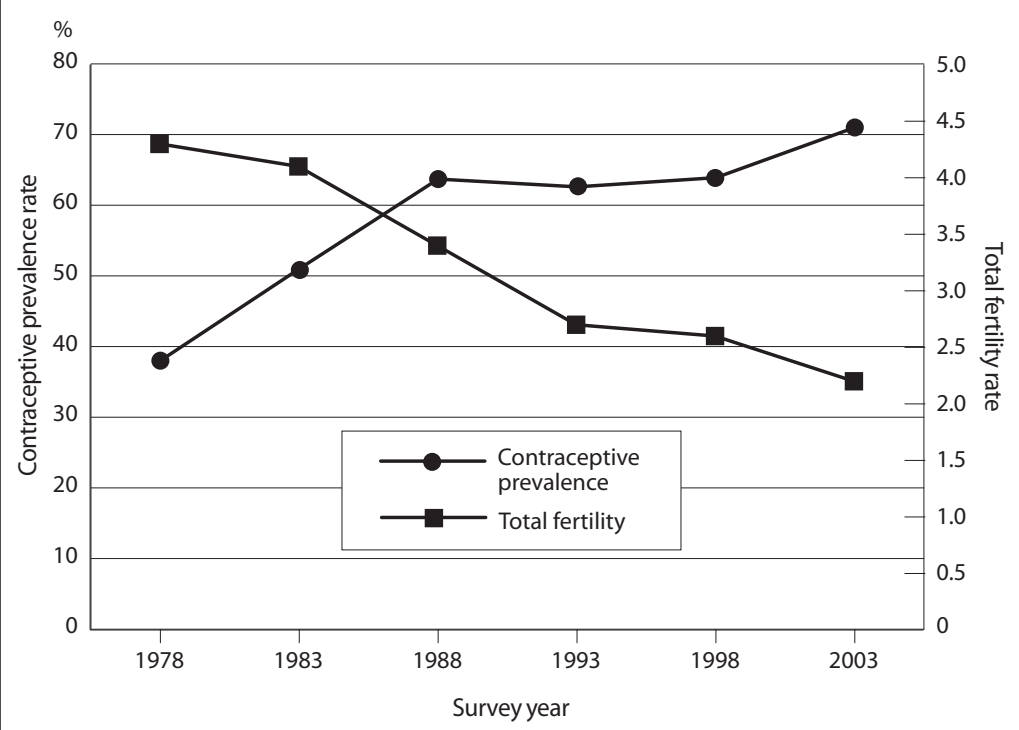

Sources: Compiled from quinquennial demographic and family planning surveys (references 23 and 24).

partner's report and help assess reliability. Second, we examine the influence of husband-wife communication and interspousal power relations on couples' current use of contraceptives, and attempt to determine if a joint decision-making model is becoming the norm. Third, after adjusting for background demographic and socioeconomic factors, we compare results from models of the relative influences of spousal attitudes and preferences, effective partner communication and gender-based power differentials on current contraceptive use, based on husbands', wives' and joint reports of use. Such an assessment is needed in the Middle East, particularly as it moves toward a more advanced stage of fertility transition. Studies on these topics are generally lacking for countries with intermediate fertility levels, defined by the United Nations as having a total fertility rate between 2.1 and 5.0 children per woman. ${ }^{3}$

\section{BACKGROUND}

\section{Couple-Level Concurrence About Contraceptive Use}

The level of spousal agreement regarding fertility and family planning remains an area of scholarly contention. Although high concurrence would be expected because of daily partner contact and common living conditions, cross-national studies of couple concurrence on contraceptive method use show frequent discrepancies between husbands' and wives' reports. ${ }^{4-8}$ In one study, the median level of partners' concordance on a range of reproductive measures in DHS countries was $76 \% .{ }^{6}$ Discrepant responses may result from measurement error, social desirability biases, wives' covert use of contraceptives, and disagreement and miscommunication over spousal fertility and family planning preferences. ${ }^{7-10}$ Moreover, decisions about contraceptive use and childbearing may be compounded by unequal power relations, especially in more patriarchal societies. ${ }^{11,12}$

Until recently, researchers largely ignored the mismatches between the responses of husbands and wives and invariably assumed women's responses to be more accurate. However, the importance of assessing data from both partners has been demonstrated. ${ }^{8,13-15}$ The 1994 International Conference on Population and Development reinforced efforts to consider men in family planning and reproductive health programs and research, an imperative underscored by the HIV/AIDS epidemic. Routine data collection from men as well as women in Sub-Saharan African DHS surveys has given rise to a number of studies of spousal communication about family planning and fertility, some of which have adopted the couple as the unit of analysis. ${ }^{16,17}$ Research in Asian societies has also underscored the need to consider the preferences of both spouses. ${ }^{18-20}$ These surveys cannot be considered representative of other regions, however, particularly those where couplelevel data have yet to be analyzed.

\section{The Turkish Context}

Turkey is a low-to-middle-income country located at the intersection of southeastern Europe and the Middle East. Its population was estimated at 71 million in 2007, with an annual growth rate of $1 \%$ and an adult literacy rate of $88 \%$ ( $80 \%$ for women). ${ }^{21,22}$ The total fertility rate declined from 4.3 children per woman in 1978 to 2.6 children in $1998 ;{ }^{23}$ it fell further to 2.3 children in 2003, as Turkey moved through the middle phase of its fertility transition. ${ }^{24}$ The contraceptive prevalence rate among married women plateaued at 64\% between 1988 and 1998, and rose to $71 \%$ in 2003 (Figure 1). Because male methods account for half of all contraceptive use, it is plausible to assume that a husband's report of method use is at least as reliable as that of his wife. Factors associated with the use of withdrawal, condoms and other methods have been examined elsewhere. ${ }^{25-28}$

Despite the legal codification of gender equality following the foundation of the Turkish republic in the 1920s, various laws and social traditions have reinforced the subordinate position of women. Although Turkey does not have the rigid gender stratification found in most Middle Eastern and North African societies, violence against women-including honor killings-remains a major problem, ${ }^{29-33}$ and the Turkish parliament recently strengthened laws to protect women's rights. ${ }^{34}$ In light of increased levels of education and economic development and legal reforms that support greater gender equality, one might expect spousal reports to be quite similar. However, Turkish culture and socioeconomic structures remain maledominated. Consequently, many women may still need their husband's approval to use family planning, and husbands' attitudes and intentions may have additional effects on couples' contraceptive practice and fertility. Therefore, it is pertinent to ask whether Turkish couples have increasingly adopted joint decision making regarding family planning and fertility issues, or whether a stricter patri- 
archal system prevails.

The 2003 Turkey DHS did not collect data from men or couples, unlike the 1998 survey data examined here. A study on the consistency of couples' reports about contraceptive use and fertility preferences using the earlier DHS has been published, but it presented only measures of percentage agreement between spousal reports, ${ }^{35}$ which by itself is a crude measure of consensus. The current study also computes kappa values, which indicate the degree of agreement net of that expected by chance alone, and presents multivariate analyses using couple-level data to evaluate the influence of spousal communication and interspousal power relations on family planning practice.

\section{DATA AND METHODS}

\section{Data}

The 1998 Turkish DHS surveyed 8,576 women aged 15-49, representing 91\% of identified eligible women. The survey included 6,196 ever-married women and a subsample of husbands, drawn from about half of all surveyed households. Of the 3,043 husbands of currently married women who were identified as eligible for the survey, 1,971 were successfully interviewed. ${ }^{23}$ We matched data for these husbands with responses from their wives. The main reason for nonresponse was husbands' absence at time of interview and at repeated visits. However, differences in age, education levels and place of residence between respondents and nonrespondents were not statistically significant, ${ }^{35}$ and the total number of matched couples is higher than that for most DHS-based, couple-level studies. ${ }^{7}$

From the initial sample of 1,971 paired couples, we excluded 65 couples who reported any polygamous unions and 156 couples in which one or both partners had been married more than once. Their exclusion ensured that partners' responses would correspond to the same marital union. We further limited the sample to fecund couples in which the woman was not pregnant, because our focus was on the determinants of current contraceptive use. This led to the exclusion of 77 sterilized couples (in almost all cases because the women had been sterilized) and 127 couples who reported a current pregnancy. Thus, our final sample consisted of 1,546 matched couples for whom data were available on all variables of interest.

\section{Variables}

The social and demographic factors controlled for were age, number of living children, ethnicity, education, household wealth index, region of residence and rural-urban residence. The age variable was divided into six categories using each partner's self-reported age: husband younger than 30 and wife aged 30-39, husband aged 30-39 and wife younger than 30 , husband aged $30-39$ and wife 30 or older, husband 40 or older and wife younger than 40 , husband aged 40-49 and wife 40 or older, and husband 50 or older and wife 40 or older (the reference category). The number of children ever born and the number of living children were treated as continuous measures. Ethnicity, a politically sensitive issue in Turkey, was determined indirectly by asking respondents about their mother tongue; couples were characterized as both Kurdish or at least one spouse not Kurdish. DHS data provide the only recently available figures on the country's ethnic composition. ${ }^{36}$

Educational attainment consisted of three categories: none or incomplete primary (uneducated), primary or incomplete secondary (basic), and secondary or higher. We categorized couples' education levels as follows: both uneducated, wife basic and husband uneducated or basic, husband basic and wife uneducated, husband or wife secondary or higher, and both secondary or higher. To gauge household economic status, we constructed a household wealth index (divided into quintiles) based on the DHS approach. ${ }^{* 37,38}$ Rural-urban residence is a binary variable, and region of residence refers to the fivefold division of the country used in most social surveys. The West is the most populous, densely settled and socioeconomically advanced region; the East is the least socioeconomically developed and has the highest proportion of Kurds.

Among the intermediate variables, the number of contraceptive methods known by each partner was modeled as a continuous variable, because nearly all Turkish wives and husbands know of several methods. Attitudinal data were collected by asking respondents if they approved of couples using family planning and what they perceived as their spouse's attitude toward family planning. Respondents were also asked about their ideal family size (numerical responses were provided in nearly all cases) and if they had discussed family planning with their spouse, other relatives, neighbors or friends in the last few months. Hence, three dimensions of effective partner communication that may affect the ability of individuals and couples to negotiate contraceptive use were assessed: spousal agreement on approval, discussion between partners and spousal perception of the partner's approval of family planning. These variables are in turn related to the couple's ideal family size.

Family planning research has tended to assume women's primacy as decision makers regarding contraceptive method choice, although male prerogative and control are receiving increasing attention (e.g., in condom use and microbicide acceptability studies). We therefore constructed two indices that assess gender relations, that is, the prevailing system of socially constructed roles, norms, privileges and status between men and women: acceptance of male prerogative and of wife-beating. Separate additive indices were created from wives' and husbands' responses to the same questions; in-

*We adopted the method used by Filmer and Pritchett (reference 37) to compute a household wealth index, which is not directly available from the 1998 Turkish DHS. Principal components analysis was used to generate a weighted or factor score for each household characteristic and durable good, and these scores were summed to derive a household's wealth index; these values were then divided into approximately equal quintiles. Five characteristics were assessed: water source, toilet facility, number of rooms used for sleeping, floor type and winter heating source. The possession of 12 durable goods was assessed: refrigerator, car, television, oven, dishwasher, washing machine, vacuum cleaner, video recorder, computer, camera, CD player and cellular telephone. 
clusion of both perspectives permits better understanding of interspousal perceptions of power differentials. Acceptance of male prerogative was assessed by asking whether respondents agreed or disagreed with four statements: that important family decisions should be made by men, that men are usually wiser than women, that a woman should not argue with her husband and that it is better for the male child to be educated than the female child. Acceptance of wife-beating was based on whether respondents agreed that the husband had a right to beat his wife in three situations: if his wife argued with him, if she talked with other men or if she spent money needlessly. Greater gender-based power differentials may be associated with lower contraceptive use; conversely, joint decision-making norms tend to characterize societies with high contraceptive prevalence and low fertility. A basic tenet in reproductive health program management and policy making is that joint decision making helps realize women's empowerment and health goals.

In our multivariate analyses, these two measures were modeled as dummy variables (i.e., for each index, whether respondents agreed with at least two of the statements). The outcome variable-current contraceptive use-refers to both modern and traditional methods used in the past year. Wives' and husbands' reports were treated as separate outcomes. A further aim of the study, therefore, is to assess if similar predictors of contraceptive use result from models based on the three sets of regression analyses.

\section{Analysis}

We first assessed spousal concordance on selected survey questions: whether the wife was pregnant, contraceptive use while the wife was pregnant and knowledge of condom use. We also determined the degree of concordance between spousal reports on other variables, including specific fertility and family planning items. We calculated both the percentage of couples whose responses were in agreement and the kappa statistic. ${ }^{39}$ Kappa values may range from -1 to 1 ; a value of 0 indicates that agreement could occur by chance, and negative values indicate disagreement. Positive values of $0-0.20$ suggest slight agreement, 0.21-0.40 fair agreement, $0.41-0.60$ moderate agreement and $0.61-0.80$ substantial concurrence. Higher values indicate almost perfect agreement beyond chance. ${ }^{39,40}$

Multiple logistic regression was used to examine the influence of explanatory variables on current contraceptive use. After controlling for the effects of demographic and socioeconomic variables, we hypothesized, couples' contraceptive use is positively associated with the contraceptive knowledge of both spouses, as well as with their approval of family planning, spousal communication about family planning and husband-wife agreement regarding fertility preferences. We further hypothesized that gender-based power imbalances may constrain women's negotiation ability and affect patterns of contraceptive decision making.

We computed and compared separate multivariate models using wives' and husbands' reports of current contraceptive use, and show two sets of models for each. The first
TABLE 1. Selected fertility and family planning measures, as reported by wives aged 15-49 and their husbands, percentage of these couples $(N=1,546)$ whose responses were in agreement and associated kappa values, 1998 Turkish Demographic and Health Survey

Measure Wives Husbands $\begin{array}{lll}\% \text { in } & \text { Kappa } \\ \text { agree- } & \text { value } \\ \text { ment } \dagger\end{array}$

MEANS

Fertility and

contraceptive use

No. of living children

No. of children ever born

No. of methods ever used $\neq$

2.6

2.8

2.6

2.9

98.5

PERCENTAGES

Contraceptive use

Currently using a method $\neq \quad 72$.

Ever used any method $\neq$

$\begin{array}{ll}72.0 & 68.0\end{array}$

68.0

85.3

44.6

47.5

Ever used a condom $\neq$

$54.9 \quad 0.45$

Family planning

Respondent approves

Spouse approves§

90.2

Discussed with spouse

82.7

84.9

82.0

$83.1 \quad 0.23$

$77.3 \quad 0.22$

$89.8 \quad 0.09$

†The response "don't know" was classified as discordant. ¥Some discordant responses may be due to sexual relations with other partners either before or outside of marriage. §According to respondent.

set included all the intermediate variables, and the second set also adjusted for background variables whose influence on contraceptive use has been well established in previous research. We then ran a combined model based on 1,250 couples for whom concordant reports were obtained, with the dependent variable coded as 1 if both partners reported contraceptive use and as 0 if neither reported use.

\section{RESULTS}

\section{Concurrence Between Spousal Reports}

Independent sources of information, such as biomarkers of semen exposure or clinic records, were not available to validate respondents' self-reports of contraceptive use. Therefore, we examined consistency of reporting both in the overall couples data set and in the study sample. Of all 1,906 monogamous couples in the data set, a husband reported current contraceptive use while his wife was pregnant in only 18 cases. This rate is lower than that for 23 DHS countries studied elsewhere ${ }^{6}$ and suggests good overall data quality. The validity of other survey items cannot be readily assessed, but measurement accuracy can be assessed by testing the reliability of both partners' responses to other questions. Although some inconsistencies between husbands' and wives' reports were found, overall they were minor compared with those observed for most DHS surveys. In $92 \%$ of the cases in which wives said they were currently pregnant, husbands also reported the pregnancy. In $80 \%$ of the cases of disagreement, the wives were in the first four months of pregnancy.

Concurrence tests run on the study sample of 1,546 couples indicated generally good agreement between spousal reports. Furthermore, among respondents who said they did not know of condoms, none reported con- 
dom use. However, $68 \%$ of husbands and $83 \%$ of wives claimed to know of condoms, yet matched responses indicated that in only $59 \%$ of the couples did both partners know about this method. The kappa value for this level of agreement was poor (0.12).

Spousal reports of the two fertility measures showed high agreement and kappa values (93-99\% and 0.930.99 , respectively; Table 1 ), whereas these values for the number of contraceptive methods ever used were low (38\% and 0.25 , respectively). For the last measure, some discordant responses may be due to sexual relations with other partners either before or outside of marriage. Reports of current method use were slightly lower among husbands than among wives (68\% vs. $72 \%$ ), but the level of agreement was $81 \%$ and the kappa statistic (0.56) suggests moderate concurrence beyond chance.

Discrepancies were also found in partners' attitudes toward and discussion of family planning. In $83 \%$ of couples, partners held similar attitudes toward family planning (85-90\% of individual respondents expressing approval), although the kappa value (0.23) suggests only fair agreement. Spousal perceptions of each other's attitudes toward family planning showed similar levels of concordance with their spouse's actual attitudes. The percentage agreement for discussing family planning with one's spouse was 90\%; however, the low kappa value (0.09) indicates that chance identical responses among spouses were high. Few discussions were reported (5-7\%), but the reference period for this question was limited to the last two months rather than the past year, as is customary in DHS surveys.

\section{Sample Characteristics}

The level of agreement between spousal reports on specific fertility and family planning items was relatively high. Knowledge of contraceptive methods was almost universal in all subgroups of background characteristics. In 98\% of couples, the wife and husband knew of at least one method; on average, wives knew of seven methods and husbands at least six (Table 2). About nine out of 10 wives and husbands approved of family planning, and almost identical proportions ( $83 \%$ and $82 \%$, respectively) thought their spouses approved of family planning. Overall, $74 \%$ of wives and $77 \%$ of husbands accurately reported their spouse's approval; in 77\% and 78\% of these cases, respectively, spouses' reports were in agreement (i.e., both approved or both disapproved; not shown).

Levels of reported discussion of family planning were low, and were probably related to the unusually short reference period for this item. Such discussions were rare among spouses (5-7\%), and more frequent with other relatives, neighbors or friends (23-27\%). Given the low level of spousal discussion and the low kappa value noted earlier, this variable was dropped from the multivariate analyses. Wives and husbands had similar preferences regarding ideal family size, with high proportions (84\% and $82 \%$, respectively) wanting three or fewer children.
TABLE 2. Means (and standard deviations) and percentage distributions of wives and their husbands, by selected intermediate and background variables

Variable

Wives Husbands

INTERMEDIATE

Mean no. of known contraceptive methods $7.1(2.2) \quad 6.4(2.2)$

Approves of family planning

Yes

$90.4 \quad 85.3$

Discussed family planning

With spouse

With others

$9.6 \quad 14.7$

Did not discuss/don't know

$\begin{array}{ll}7.2 & 4.7\end{array}$

Perceives that spouse approves of family planning

$\begin{array}{lll}\text { Yes } & 82.7 & 82.0\end{array}$

$\begin{array}{lll}\text { No } & 82.7 & 82.0 \\ & 17.3 & 18.0\end{array}$

Ideal family size

Wants $\leq 3$ children $\quad 84.1$

$\begin{array}{lll}\text { Wants }>3 \text { children } & 15.9 & 17.7\end{array}$

Acceptance of male prerogative

$\begin{array}{lll}\text { No statements } & 39.0 & 31.5\end{array}$

1 statement $\quad 20.6 \quad 20.8$

2 statements $\quad 13.5 \quad 18.6$

3 statements $\quad 14.7 \quad 16.8$

$\begin{array}{lll}4 \text { statements } & 12.2 & 12.4\end{array}$

Acceptance of wife-beating

No situations

1 situation

2 situations

3 situations

$19.0 \quad 23.3$

$15.6 \quad 19.8$

BACKGROUND

Mean no. of living children

$2.6(1.8)$

$2.6(1.8)$

Age

30-39

$40-49$

$\geq 50$

$37.5 \quad 22.7$

$36.0 \quad 36.5$

$26.6 \quad 30.7$

na $\quad 10.1$

Education

None

Primary/incomplete secondary

$23.1 \quad 8.6$

zsecondary

$61.2 \quad 65.5$

Household wealth index

Poorest quintile

Lower middle quintile

Middle quintile

Upper middle quintile

Wealthiest quintile

$15.7 \quad 25.9$

Total

$14.5 \quad 14.5$

$18.7 \quad 18.7$

$21.4 \quad 21.4$

$22.3 \quad 22.3$

$23.0 \quad 23.0$

$100.0 \quad 100.0$

Notes: The total number of couples $(1,546)$ has been weighted by the coupleweight provided by DHS, so the distributions shown are for 1,552 couples. na=not applicable.

The two measures of interspousal power relations showed that about half or more of all wives and husbands agreed with at least one statement of male prerogative and agreed that in some situations, husbands have a right to assert authority through physical violence. Wives were only slightly less likely to agree with these propositions. Acceptance of wife-beating is more directly linked to interspousal power relations than is male prerogative, and it was therefore included in the regression analyses. 
TABLE 3. Percentage distribution of married couples, by selected intermediate and background variables

Variable

INTERMEDIATE

Approval of family planning

Both approve

Only wife approves

Only husband approves

Both disapprove

79.2

11.1

5.8

4.0

Ideal family size

Both want $\leq 3$ children

Only wife wants $\leq 3$ children

Only husband wants $\leq 3$ children

Both want $>3$ children

BACKGROUND

Age

Husband $<30$, wife 30-39 22.7

Husband 30-39, wife $<30 \quad 14.9$

Husband 30-39, wife $\geq 30$

Husband $\geq 40$, wife $<40$

Husband 40-49, wife $\geq 40 \quad 16.2$

Husband $\geq 50$, wife $\geq 40$

Ethnicity

Both Kurdish

At least one not Kurdish

8.2

Education

Both uneducated

Wife basic, husband uneducated/basic

Husband basic, wife uneducated

At least one $\geq$ secondary

Both $\geq$ secondary

Region

West

South

Central

North

East

Residence

Urban

Rural

Total

100.0

†“Uneducated" includes none and incomplete primary, and "basic" includes primary and incomplete secondary. Note: The total number of couples $(1,546)$ has been weighted by the couple-weight provided by DHS, so the distributions shown are for 1,552 couples.

Spousal agreement about family planning and ideal family size was also high. In $79 \%$ of married couples, both spouses approved of family planning, and in $4 \%$ neither partner approved; in the remaining $17 \%$ of couples, only one partner approved (Table 3). Seventy-three percent of couples wanted three or fewer children, and overall $80 \%$ agreed about their fertility preference. Husband-wife inconsistencies were primarily attributable to the wife wanting fewer children than her husband would like.

\section{Multivariate Findings}

In the first model in Table 4, the outcome variable was wives' reports of contraceptive use; the model included intermediate variables only. The odds of current use rose with the number of methods known by the wife (odds ratio, 1.2). Couples in which the husband alone approved of family planning and those in which the wife perceived that her husband approved also had higher odds of current use (2.3 and 3.1, respectively). Acceptance of wifebeating was of borderline significance (1.1).

In the final model, which added background factors, the number of contraceptive methods known by the wife and the wife's perception that her husband approved of family planning were the only intermediate variables that retained significance (odds ratios, 1.2 and 3.3, respectively). As expected, contraceptive use was more likely among younger couples than in the oldest age-group (3.0-11.5), and was positively associated with number of living children (1.4). Couples in which both spouses were Kurdish, were uneducated or were living in the East had decreased odds of using a method (0.4-0.6).

The initial model using husbands' reports of contraceptive practice as the outcome showed that both the number of contraceptive methods known by the husband and his perception that his wife approved of family planning were associated with an increased likelihood of contraceptive use (odds ratios, 1.1 and 2.1, respectively), similar to findings from the wives' initial model. Couples in which one or both spouses approved of family planning had higher odds of using a method than if neither approved (5.0-8.9). Compared with couples in which both spouses wanted three or fewer children, those in which only the husband wanted three or fewer or both wanted more than three had lower odds of contraceptive use (0.6 each). The husband's acceptance of wife-beating was not associated with contraceptive use.

In the husbands' final model, the odds of use rose with the number of methods he knew (odds ratio, 1.1). Approval of family planning by one or both spouses was associated with higher odds of use than disapproval by both (3.8-5.8), and the husband's perception that his wife approved was associated with higher odds than a perception that she disapproved (2.0). Measures of ideal family size did not retain significance in this model. Except for residence in the East, the same background factors that were significantly correlated with contraceptive use in the wives' final model were also significant here, with the addition of being in either the lower-middle or upper-middle household wealth quintile.

Our last set of regression analyses combined spouses' reports on the same covariates, using concordant joint reports on contraceptive use as the dependent variable. We excluded knowledge of contraceptive methods and perception of the spouse's approval of family planning, because separate spousal reports for these items cannot be readily combined as couple variables. When both intermediate and background factors were included, couples in which both spouses approved of family planning had higher odds of practicing contraception than if only one or neither of them approved (odds ratio, 2.4-Table 5, page 134). Furthermore, couples who both wanted more than three children, and couples in which only the wife wanted three or fewer, had lower odds of using a method than did couples in which both spouses wanted three or fewer chil- 


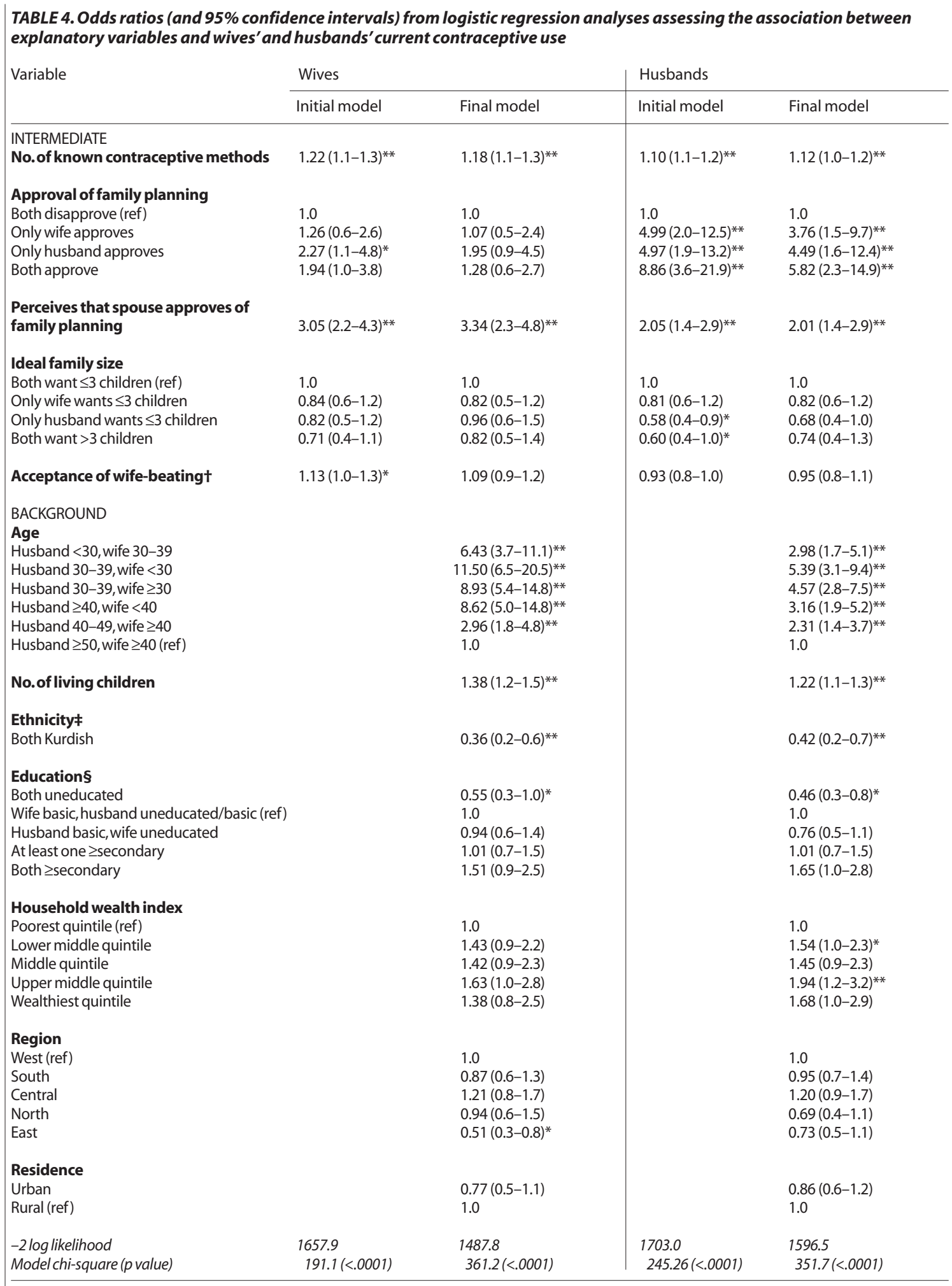

${ }^{*} \mathrm{p}<.05 .{ }^{* *} \mathrm{p}<.01$. TRespondents were considered to accept wife-beating if they agreed with at least two of the statements; the reference category was agreeing with none or only one statement. ₹The reference category was at least one spouse characterized as not Kurdish. § "Uneducated" includes none and incomplete primary, and "basic" includes primary and incomplete secondary. Note: ref=reference category.

dren (0.4 and 0.6, respectively). In this model, acceptance of wife-beating by either spouse was not associated with contraceptive use.

Current contraceptive use by couples was associated with age: Compared with the oldest spouses, all other age categories had elevated odds of using a method (odds ratios, 3.5-14.6). Method use was positively associated with the number of living children (1.5), higher household wealth index (2.2-3.4) and residence in the Central region (1.7). In contrast, contraceptive use was negatively associ- 
TABLE 5. Odds ratios (and 95\% confidence intervals) from logistic regression analyses assessing the association between explanatory variables and couples'current contraceptive use

\begin{tabular}{|c|c|c|}
\hline Variable & Initial model & Final model \\
\hline \multicolumn{3}{|l|}{ INTERMEDIATE } \\
\hline $\begin{array}{l}\text { Both approve of family } \\
\text { planning }\end{array}$ & $4.0(3.0-5.6)^{* *}$ & $2.40(1.6-3.5)^{* *}$ \\
\hline \multicolumn{3}{|l|}{ Ideal family size } \\
\hline Both want $\leq 3$ children (ref) & 1.0 & 1.0 \\
\hline Only wife wants $\leq 3$ children & $0.65(0.4-1.0)^{*}$ & $0.63(0.4-1.0)^{*}$ \\
\hline Only husband wants $\leq 3$ children & $0.48(0.3-0.7)^{* *}$ & * $0.63(0.4-1.1)$ \\
\hline Both want $>3$ children & $0.35(0.2-0.6)^{* *}$ & * $\quad 0.44(0.2-0.8)^{* *}$ \\
\hline \multicolumn{3}{|l|}{ Acceptance of wife-beating $t$} \\
\hline \multicolumn{3}{|l|}{ Wife accepts } \\
\hline Yes & $0.94(0.8-1.1)$ & $0.97(0.8-1.1)$ \\
\hline No (ref) & 1.00 & 1.00 \\
\hline \multicolumn{3}{|l|}{ Husband accepts } \\
\hline Yes & $0.93(0.8-1.1)$ & $0.98(0.8-1.2)$ \\
\hline No (ref) & 1.00 & 1.00 \\
\hline \multicolumn{3}{|l|}{ BACKGROUND } \\
\hline \multicolumn{3}{|l|}{ Age } \\
\hline \multicolumn{2}{|l|}{ Husband $<30$, wife $30-39$} & $6.48(3.5-12.1)^{* *}$ \\
\hline \multicolumn{2}{|l|}{ Husband 30-39, wife $<30$} & $14.58(7.3-29.0)^{* *}$ \\
\hline \multirow{2}{*}{\multicolumn{2}{|c|}{ Husband $30-39$, wife $\geq 30$}} & $10.41(5.8-18.7)^{* *}$ \\
\hline & Husband $\geq 40$, wife $<40$ & $7.99(4.3-14.8)^{* *}$ \\
\hline \multicolumn{2}{|l|}{ Husband $40-49$, wife $\geq 40$} & $3.53(2.0-6.1)^{* *}$ \\
\hline \multicolumn{2}{|l|}{ Husband $\geq 50$, wife $\geq 40$ (ref) } & 1.0 \\
\hline \multicolumn{2}{|l|}{ No. of living children } & $1.47(1.3-1.7)^{* *}$ \\
\hline \multicolumn{3}{|l|}{ Ethnicity¥ } \\
\hline \multicolumn{2}{|l|}{ Both Kurdish } & $0.22(0.1-0.4)^{* *}$ \\
\hline \multicolumn{3}{|l|}{ Education§ } \\
\hline \multicolumn{2}{|l|}{ Both uneducated } & $0.28(0.1-0.6)^{* *}$ \\
\hline \multirow{2}{*}{\multicolumn{2}{|c|}{$\begin{array}{l}\text { Wife basic, husband } \\
\text { uneducated/basic (ref) }\end{array}$}} & \\
\hline & & $\begin{array}{l}1.0 \\
0.66(0.4-1.0)\end{array}$ \\
\hline \multicolumn{2}{|l|}{ At least one $\geq$ secondary } & $1.21(0.8-1.9)$ \\
\hline \multicolumn{2}{|l|}{ Both $\geq$ secondary } & $1.83(1.0-3.4)$ \\
\hline Household wealth index & & \\
\hline Poorest quintile (ref) & & 1.0 \\
\hline Lower middle quintile & & $2.16(1.3-3.7)^{* * *}$ \\
\hline Middle quintile & & $2.44(1.4-4.3)^{* * *}$ \\
\hline Upper middle quintile & & $3.36(1.8-6.3)^{* * *}$ \\
\hline Wealthiest quintile & & $2.96(1.5-5.9)^{* * *}$ \\
\hline Region & & \\
\hline West (ref) & & 1.0 \\
\hline South & & $0.92(0.6-1.4)$ \\
\hline Central & & $1.68(1.1-2.7)^{*}$ \\
\hline North & & $0.81(0.5-1.5)$ \\
\hline East & & $0.52(0.3-0.9)^{*}$ \\
\hline Residence & & \\
\hline Urban & & $0.64(0.4-1.0)^{*}$ \\
\hline Rural (ref) & & 1.0 \\
\hline$-2 \log$ likelihood & $294.3 \quad 1$ & 1085.2 \\
\hline Model chi-square ( $p$ value) & $141.46(<.0001)$ & $350.59(<.0001)$ \\
\hline
\end{tabular}

${ }^{*} p<.05 .{ }^{* *} p<.01$. TRespondents were considered to accept wife-beating if they agreed with at least two of the statements; the reference category was agreeing with none or only one statement. $¥$ The reference category was at least one spouse characterized as not Kurdish. §"Uneducated" includes none and incomplete primary, and "basic" includes primary and incomplete secondary. Note: ref=reference category.

ated with both spouses being Kurdish, both spouses being uneducated, living in the East and urban residence $(0.2-0.6)$.

\section{DISCUSSION}

This study adds to the growing body of couple-level research from around the world and provides more evidence that information from one spouse cannot fully represent the views of the other partner, nor of the couple. Many problems and unresolved issues remain regarding the validity and reliability of either partner's sole reports, as well as of couples' data. The challenge remains to build on existing work and to improve the measurement, modeling and use of couple-level data.

In 1998, Turkish husbands reported a contraceptive prevalence rate that was $4 \%$ lower than that of their wives. The net difference is relatively small compared with that found in many other developing countries. However, its direction differs from the more common pattern, in which husbands report higher levels of use than do their wives because they report more use of condoms or periodic abstinence. ${ }^{7,10}$ Compared with their wives, Turkish husbands underreport use of condoms and withdrawal (though wives report less pill use and more IUD use than do their husbands). Studies from many countries indicate that use of withdrawal is frequently underreported. ${ }^{41,42}$ Factors that predict the choice of withdrawal over other contraceptive methods in Turkey have been examined elsewhere. ${ }^{25-28}$

As in other studies, spouses' proxy reports on factual variables-including fertility-related items such as number of living children-showed much stronger concordance than that found for attitudinal variables, which, by definition, are more subjective. However, the widely used kappa statistic may be affected by the prevalence of the observed findings, as well as of discordant responses, and it is not unambiguously clear what constitutes good agreement. This study has employed perhaps the most widely adopted grading system of kappa, but all existing scales are based on arbitrary subdivisions. ${ }^{40,43}$ Future work should consider the suitability of alternative indices of agreement for couple-level studies of reproductive decision making.

Our multivariate analyses excluded the measure of whether family planning was discussed because of the low reported prevalence of this behavior and its low kappa value, doubtless related to the unusually short time frame considered. In actuality, such discussion is almost certainly far more common, not least because one in four Turkish couples rely on withdrawal, a method that requires active spousal cooperation. Additionally, this measure referred only to the frequency of discussion, not to its actual content, nature or quality. Although there may be some theoretical ambiguity in the relationship between contraceptive use and husband-wife agreement and communication regarding attitudes and preferences, other communication variables were associated with contraceptive use after background variables were controlled for. Such influences were not found to be moderated by interspousal power relations, although our measures were imperfect. A longitudinal analysis has confirmed cross-sectional findings that spousal communication is associated with greater contraceptive use. $^{44}$ 
For both initial multivariate models based on separate spousal reports, intermediate variables that had positive associations with current contraceptive use included the couple's knowledge of contraceptive methods, the husband's approval of family planning and each spouse's perception of the other's approval. Wives' acceptance of wifebeating was marginally significant, but not in the final model based on their reports. After controlling for background variables, the approval of family planning retained significance only in the model based on husbands' reports of contraceptive use. However, this is an attitudinal variable for which the kappa value suggested only fair agreement when accounting for chance. Other than residence in the East region and being in either the lower-middle or upper-middle wealth quintiles, the same background factors were found to be associated with contraceptive use in the final models based on separate spousal reports.

To some extent, our results may reflect a high social desirability of reporting joint decision making and not necessarily actual joint decision making. They also cannot resolve whose reports and preferences are more valid and influential in reproductive decision making. However, consideration of separate and combined models using reports from each spouse may help detect inconsistencies between spousal reports and lead to insights not attainable in simpler, single-partner formulations, which may presume differences between spouses and genders when none exist. Although spousal reporting differences regarding family planning were not major, neither were they inconsequential. Other researchers have proposed guidelines as to which set of reports (those of wives, husbands or both) should be used to obtain the best estimate of contraceptive use, ${ }^{7,45}$ but guidance varies. The resulting inconsistency and uncertainty regarding such rules further underscore the need for more research on this topic.

Several factors may account for the difference between the results of the combined multivariate model and those from the separate models. We could not include two of our original spousal communication variables and we excluded discrepant reports. Although our two dyad members (husband and wife) are distinguishable, they are not strictly independent. Marriage implies that two individuals come together to form a couple, and they tend to stay married because they see life in a similar way; consequently, they are likely to seek a consensus on matters of mutual importance. More broadly, statistical nonindependence in dyads may be due to compositional, partner, mutual influence and common fate effects, ${ }^{46,47}$ all of which are observed within marriage. For example, compositional factors refer to the similarity of married couples across a range of variables. In Turkey, where kin-based structures remain strong, assortative mating may be more likely than in the more open, individualistic societies of Europe or North America. In addition, standard statistical methods developed for the study of individuals to address issues of stability, consistency and correlations between related quantitative measurements may not be well-suited for an- alyzing couple-level data. ${ }^{47}$ In the absence of greater conceptual and methodological clarity, it is not surprising that most researchers continue to use individual-centered models and statistical tools.

Treating dyadic data as if they are two samples is less than optimal, however. The phenomena we wish to study are interpersonal by definition, and our measures of contraceptive use and fertility reflect the contributions of two persons and their resolution within the couple. A key problem that remains is how to conceptualize the respective influences of each spouse on the other, while at the same time modeling the statistical interdependence that exists between partners. Much more work is needed in this area to better conceptualize and solve long-standing analytic problems in couple-level studies of contraceptive use and reproductive decision making.

Several questions in this study evaluated the influence of interspousal power relations on contraceptive use. About half of all Turkish wives and husbands accept that a husband is entitled to beat his wife should she not obey him. It may seem surprising, therefore, that our measures of power relations were not associated with contraceptive use in any of the final models. This may indicate that gender dynamics are moving toward greater equilibrium between the sexes. Although researchers often portray marriage as a power game, many spouses may negotiate with each other to resolve issues. However, our variables do not capture all the dimensions of power relations. Gender inequalities are strongly evident in the sexual sphere in Turkey, where premarital sex is disapproved for women but tolerated and even expected for young men. ${ }^{48}$

To some extent, gender inequality may be less relevant in contraceptive decision making in Turkey, given the relatively strong tradition that husbands assume some responsibility for contraception. ${ }^{25,49}$ This may partly counterbalance other gender effects arising from a husband's generalized power in marriage against the "female sphere" of influence. However, the degree of involvement by Turkish husbands in contraceptive use should not be exaggerated, as evidenced by the very low prevalence of vasectomy (less than $0.1 \%$ of husbands) as compared with tubal sterilization (about $4 \%$ of wives). Furthermore, the two variables used to capture gender-based power differentials had the expected negative associations with contraceptive use in bivariate logistic regressions, with the results highly significant in all cases ( $\mathrm{p}<.01$; not shown). Presumably, both of these variables are highly correlated with education level and perhaps some other factors, which reduces their significance in our multivariate logistic regression models.

\section{Conclusions}

Discrepant spousal reports are not unusual in Turkey, but they do appear to be less significant than in most low-tomiddle-income countries with DHS data. We did not find evidence that interspousal power relations play a significant explanatory role in contraceptive use. Although our 
measures are imperfect, we conclude that most Turkish couples appear to have moved toward a more egalitarian mode of reproductive decision making than that believed to characterize other Middle Eastern countries. The views of both spouses matter and contribute to a fuller understanding of how couples decide on their contraceptive practice. Further research is needed to better conceptualize and assess longstanding analytic problems in couplelevel studies.

\section{REFERENCES}

1. Warren CW et al., Fertility and family planning in Jordan: results from the 1985 Jordan Husbands' Fertility Survey, Studies in Family Planning, 1990, 21(1):33-39.

2. Ünalan T, Problems of collecting information from men in demographic surveys: experience from the 1988 Turkish Population and Health Survey, paper presented at the IUSSP Seminar on Men, Family Formation and Reproduction, Buenos Aires, Argentina, May 13-15, 1998.

3. United Nations (UN), Fertility levels and trends in countries with intermediate levels of fertility, in: Fertility, Contraception and Population Policies, New York: UN, 2003, pp. 136-168.

4. Koenig MA, Simmons GB and Misra BD, Husband-wife inconsistencies in contraceptive use responses, Population Studies, 1984, 38(2):281-298.

5. Bankole A and Singh S, Couples' fertility and contraceptive decisionmaking in developing countries: hearing the man's voice, International Family Planning Perspectives, 1998, 24(1):15-24

6 . Becker S, Couples and reproductive health: a review of couple studies, Studies in Family Planning, 1996, 27(6):291-306.

7. Becker S and Costenbader E, Husbands' and wives' reports of contraceptive use, Studies in Family Planning, 2001, 32(2):111-129.

8. Ezeh AC and Mboup G, Estimates and explanations of gender differentials in contraceptive prevalence rates, Studies in Family Planning, 1997, 28(2):104-121.

9. Miller K, Zulu EM and Watkins SC, Husband-wife survey responses in Malawi, Studies in Family Planning, 2001, 32(3):161-174.

10. Salem R, Men's surveys: new findings, Population Reports, 2004 Series M, No. 18

11. Blanc AK, The effect of power in sexual relationships on sexual and reproductive health: an examination of the evidence, Studies in Family Planning, 2001, 32(3):189-213

12. Grady WR et al., The role of relationship power in couple decisions about contraception, paper presented at the annual meeting of the Population Association of America, New York, Mar. 29-31, 2007.

13. Bledsoe C, Lerner S and Guyer JI, eds., Fertility and the Male LifeCycle in the Era of Fertility Decline, Oxford, UK: Oxford University Press, 2000.

14. Greene ME and Biddlecom AE, Absent and problematic men: demographic accounts of male reproductive roles, Population and Development Review, 2000, 26(1):81-115.

15. Voas D, Conflicting preferences: a reason fertility tends to be too high or too low, Population and Development Review, 2003, 29(4):627-646.

16. DeRose LF and Ezeh AC, Men's influence on the onset and progress of fertility decline in Ghana, 1988-98, Population Studies, 2005, 59(2):197-210.

17. Dodoo F N-A, Men matter: additive and interactive gendered preferences and reproductive behavior in Kenya, Demography, 1998, 35(2):229-242.

18. Biddlecom AE, Casterline JB and Perez AE, Spouses' views of contraception, International Family Planning Perspectives, 1997, 23(3):108115.
19. Mason K and Smith H, Husbands' versus wives' fertility goals and use of contraception: the influence of gender context in five Asian countries, Demography, 2001, 37(3):299-311.

20. Jejeebhoy S, Convergence and divergence in spouses' perspectives on women's autonomy in rural India, Studies in Family Planning, 2002, 33(4):299-308.

21. U.S. Bureau of the Census, International data base country summary: Turkey, <http://www.census.gov/ipc/www/idb/country/ tuportal.html>, accessed Feb. 24, 2008.

22. Turkish Statistical Institute, Population and development indicators, 2007, <http://nkg.die.gov.tr/en/goster.asp?aile=3>, accessed Feb. 24, 2008.

23. Hacettepe University Institute of Population Studies (HIPS) and Macro International, Inc., Turkish Demographic and Health Survey, 1998 Ankara, Turkey: HIPS; and Calverton, MD, USA: Macro International, Inc., 1999.

24. HIPS, Turkey Demographic and Health Survey, 2003, Ankara, Turkey: HIPS, 2004

25. Kulczycki A, The determinants of withdrawal use in Turkey: a husband's imposition or a woman's choice? Social Science $\&$ Medicine, 2004, 59(5):1019-1033.

26. Ortayli N et al., Why withdrawal? Why not withdrawal? Men's perspectives, Reproductive Health Matters, 2005, 13(25):164-173.

27. Ergöçmen BA et al., An Analytical Insight into a Traditional Method: Withdrawal Use in Turkey, Ankara, Turkey: HIPS; and Calverton, MD, USA: ORC Macro, 2001

28. Yannikkerem E, Acar $\mathrm{H}$ and Elem E, Withdrawal users' perceptions of and experience with contraceptive methods in Manisa, Turkey, Midwifery, 2006, 22(3):274-284

29. UN Development Programme (UNDP), Arab Human Development Report 2003, New York: UNDP, 2003.

30. Freedom House, Women's Rights in the Middle East and North Africa: Citizenship and Justice, New York: Freedom House, 2005

31. Ergöçmen BA, Women's status and fertility in Turkey, in: HIPS and Macro International, Inc., eds., Fertility Trends, Women's Status, and Reproductive Expectations in Turkey: Results of Further Analysis of the 1993 Turkish Demographic and Health Survey, Ankara, Turkey: HIPS and Calverton, MD, USA: Macro International, Inc., 1997, pp. 81-104

32. Arat ZF, ed., Deconstructing Images of the Turkish Woman, New York: Palgrave Macmillan, 1998

33. Kardam N, Turkey's Engagement with Global Women's Human Rights, Aldershot, Hampshire, UK: Ashgate, 2005.

34. Anil E et al., Turkish Civil and Penal Code Reforms from a Gender Perspective: The Success of Two Nationwide Campaigns, Women for Women's Human Rights-New Ways, 2005, <http://www.wwhr.org/ images/CivilandPenalCodeReforms.pdf>, accessed Aug. 30, 2008.

35. Akin L and Ozaydin N, Consistency of couple declaration about using family planning methods in Turkey, Journal of Biosocial Science, 2006, 38(6):735-744

36. Sirkeci I, Exploring the Kurdish population in the Turkish context, Genus, 2000, 56(1-2):149-175.

37. Filmer D and Pritchett L, The effect of household wealth on educational attainment: evidence from 35 countries, Population and Development Review, 1999, 25(1):85-120.

38. Rutstein SO and Johnston K, The DHS Wealth Index, DHS Comparative Reports, Calverton, MD, USA: ORC Macro, 2004, No. 6

39. Cohen J, A coefficient of agreement for nominal scales, Educational and Psychological Measurement, 1960, 20(1):37-46.

40. Landis JR and Koch GG, The measurement of observer agreement for categorical data, Biometrics, 1977, 33(1):159-174.

41. Santow G, Coitus interruptus in the twentieth century, Population and Development Review, 1993, 19(4):767-792.

42. Tsui AO, DeSilva SV and Marinshaw R, Pregnancy avoidance and coital behavior, Demography, 1991, 28(1):101-107. 
43. Rigby AS, Statistical methods in epidemiology. V. towards an understanding of the kappa coefficient, Disability and Rehabilitation, 2000, 22(8):339-344

44. Bawah AA, Spousal communication and family planning behavior in Navrongo: a longitudinal assessment, Studies in Family Planning, 2002, 33(2):185-194.

45. Bankole A and Ezeh AC, Unmet need for couples: an analytical framework and evaluation with DHS data, Population Research and Policy Review, 1999, 18(6):579-605.

46. Kenny DA, Models of nonindependence in dyadic research, Journal of Social and Personal Relationships, 1996, 13(2):279-294.

47. Kenny DA, Kashy DA and Cool WL, Dyadic Data Analysis, New York: Guilford Press, 2006.

48. Aras $S$ et al., Sexual behaviours and contraception among univer sity students in Turkey, Journal of Biosocial Science, 2007, 39(1):121135

49. Angin Z and Shorter FC, Negotiating reproduction and gender during the fertility decline in Turkey, Social Science $\&$ Medicine, 1998, 47(5):555-564.

\section{RESUMEN}

Contexto: En Turquía, el uso de anticonceptivos ha continuado extendiéndose, pero se sabe poco acerca de la consistencia de los informes de los esposos o sobre la influencia relativa de la comunicación, características de la toma de decisiones y diferenciales de poder en el uso de métodos.

Métodos: Se examinó una serie de datos de la Encuesta Demográfica y de Salud (EDS) de 1998 en Turquía para 1,546 parejas casadas, con el fin de verificar la concurrencia entre informes de los esposos sobre variables de fecundidad y planificación familiar. Se utilizó análisis de regresión multivariado de los informes de las esposas, maridos y combinados sobre el uso actual de anticonceptivos, para evaluar la asociación entre ese uso y diferentes variables de contexto, comunicación y relaciones entre esposos.

Resultados: Los informes de los esposos sobre la mayoría de las medidas de fecundidad y uso de anticonceptivos demostraron una concordancia de moderada a alta, mientras que los informes de aprobación de planificación familiar mostraron solamente una concordancia ligera. Después de ajustar por factores de contexto, los modelos individuales basados en los informes de las esposas o de los maridos, mostraron que el número de métodos conocidos estaba asociado positivamente con el uso actual de anticonceptivos (razones de momios de, 1.2 y 1.1, respectivamente) y así lo fue la percepción de aprobación de la pareja (3.3 y 2.0, respectivamente). En el modelo de los maridos (pero no el de las esposas), se asoció con el uso actual la aprobación real de alguno de los esposos o de ambos (3.8-5.8). En el modelo combinado, se asoció positivamente con el uso de anticonceptivos la aprobación de ambos miembros de la pareja (2.4); el deseo de ambos de tener más de tres hijos, se asoció negativamente con el uso (0.4), pero el deseo de las mujeres de tener tres o menos hijos también fue negativamente asociado con el uso (0.6).

Conclusiones: Las discrepancias entre los informes de los esposos fueron menos significativas en Turquía que en la mayoría de los países en desarrollo que cuentan con datos de EDS, pero las diferencias todavía incidían de manera algo importante para explicar cómo las actitudes y preferencias de los esposos influyen en el uso de anticonceptivos. Los diferenciales de poder entre los esposos no se asociaron con el uso de métodos. Se necesita más investigación para mejorar el modelaje de esos procesos diádicos.

\section{RÉSUMÉ}

Contexte: En Turquie, la pratique contraceptive s'étend, mais la constance des déclarations conjugales et l'influence relative de la communication, de la décision et de la différence de pouvoir sur la pratique d'une méthode ne sont guère documentées. Méthodes: Les données obtenues lors de l'Enquête démographique et de santé (EDS) turque de 1998 auprès de 1.546 couples mariés ont été testées afin d'établir la concordance des déclarations conjugales sur les variables de fécondité et de planification familiale. L'association entre la pratique contraceptive courante et différentes variables de contexte, de communication et d'interaction conjugale a été évaluée par analyses de régression multivariées en fonction des déclarations relatives à cette pratique obtenues des femmes, des maris et des deux.

Résultats: Les déclarations conjugales relatives à la plupart des mesures de fécondité et de pratique contraceptive révèlent une concordance modérée à élevée, alors que celles relatives à l'approbation de la planification familiale ne présentent qu'une concordance moyenne. Après ajustement des facteurs contextuels, les modèles basés sur les déclarations des femmes et des maris révèlent une association positive entre la pratique contraceptive courante et le nombre de méthodes connues (rapports de probabilités, 1,2 et 1,1, respectivement), la perception de l'approbation du conjoint (3,3 et 2,0, respectivement) et, dans le modèle des maris, l'approbation de l'un ou l'autre des conjoints ou des deux $(3,8-5,8)$. Dans le modèle combiné, la pratique contraceptive est positivement associée à l'approbation par les deux partenaires de la planification familiale $(2,4)$ et négativement associée au désir des deux partenaires d'avoir plus de trois enfants et à celui des femmes seulement de n'en avoir que trois ou moins $(0,4$ et 0,6 , respectivement).

Conclusions: Les divergences entre les déclarations conjugales sont moins significatives en Turquie que dans la plupart des pays en développement dotés de données EDS. Les différences n'en sont pas moins révélatrices quant aux facteurs d'influence des attitudes et préférences des époux sur la pratique contraceptive. Les différences de pouvoir conjugal ne sont pas apparues associées à la pratique d'une méthode. La recherche doit être approfondie pour améliorer le test et la modélisation de ces processus dyadiques.

\section{Acknowledgments}

An earlier version of this paper was presented at the session on "Negotiation, communication and decision-making within couples in developing countries" at the IUSSP XXV International Population Conference, Tours, France, July 2005. The author thanks Eliya Zulu and Ann Biddlecom for comments.

Author contact:andrzej@uab.edu 